\title{
Antigenotoxic Effect of Trametes spp. Extracts against DNA Damage on Human Peripheral White Blood Cells
}

\author{
Aleksandar Knežević, ${ }^{1}$ Lada Živković, ${ }^{2}$ Mirjana Stajić, ${ }^{1}$ Jelena Vukojević, ${ }^{1}$ \\ Ivan Milovanović, ${ }^{1}$ and Biljana Spremo-Potparević ${ }^{2}$ \\ ${ }^{1}$ University of Belgrade, Faculty of Biology, Takovska 43, 11000 Belgrade, Serbia \\ ${ }^{2}$ University of Belgrade, Faculty of Pharmacy, Vojvode Stepe 450, 11000 Belgrade, Serbia
}

Correspondence should be addressed to Aleksandar Knežević; knezevica@bio.bg.ac.rs

Received 20 January 2015; Accepted 21 June 2015

Academic Editor: Paula B. Andrade

Copyright (C) 2015 Aleksandar Knežević et al. This is an open access article distributed under the Creative Commons Attribution License, which permits unrestricted use, distribution, and reproduction in any medium, provided the original work is properly cited.

\begin{abstract}
Trametes species have been used for thousands of years in traditional and conventional medicine for the treatment of various types of diseases. The goal was to evaluate possible antigenotoxic effects of mycelium and basidiocarp extracts of selected Trametes species and to assess dependence on their antioxidant potential. Trametes versicolor, T. hirsuta, and T. gibbosa were the species studied. Antigenotoxic potentials of extracts were assessed on human peripheral white blood cells with basidiocarp and mycelium extracts of the species. The alkaline comet test was used for detection of DNA strand breaks and alkali-labile sites, as well as the extent of DNA migration. DPPH assay was used to estimate antioxidative properties of extracts. Fruiting body extracts of T. versicolor and T. gibbosa as well as T. hirsuta extracts, except that at $20.0 \mathrm{mg} / \mathrm{mL}$, were not genotoxic agents. T. versicolor extract had at $5.0 \mathrm{mg} / \mathrm{mL}$ the greatest antigenotoxic effect in both pre- and posttreatment of leukocytes. The mycelium extracts of the three species had no genotoxic activity and significant antigenotoxic effect against $\mathrm{H}_{2} \mathrm{O}_{2}$-induced DNA damage, both in pre- and posttreatment. The results suggest that extracts of these three species could be considered as strong antigenotoxic agents able to stimulate genoprotective response of cells.
\end{abstract}

\section{Introduction}

Mushrooms have long been used as a food but equally in traditional medicine of both the western and eastern worlds [1]. Even though numerous mushrooms are recognized as healthy food $[2,3]$, their great pharmacological potential is still underutilized [4]. Nearly 60 Trametes species are known to inhabit the world but just a few of them are screened for their medicinal properties [5]. Trametes versicolor (L.:Fr.) Lloyd is the most famous medicinal species from the genus. This species, whose folk names are Turkey Tail in western cultures, Yun-Zhi (cloud-like mushroom) in China, or Kawaratake (mushroom by the river bank) in Japan, has been used for thousands of years in traditional medicine, particularly in Asia [6-8]. According to the Compendium of Chinese Materia Medica, written during the Ming Dynasty, more than 120 strains of T. versicolor have been recorded and in traditional Chinese medicinal practice this mushroom is considered useful for removing toxins, strengthening, energy increasing, improvement of liver and spleen function, and enhancing of the immune response, especially when it is dried, ground, and prepared into tea [7,9-11]. All those properties were considered very useful in folk medicine for chronic use of Trametes spp. preparations [10]. In conventional medicine the species is used mainly for the treatment of various types of cancers, but also for chronic hepatitis, rheumatoid arthritis, and infections of the respiratory, urinary, and digestive tracts, which was confirmed by numerous studies [6, 10-14]. Additionally, strong antiviral effects of some polysaccharopeptides isolated from $T$. versicolor and significant antioxidant activity of Trametes spp. fruiting body extracts have been reported [15-17]. These effects are mainly based on production of the polysaccharide krestin (PSK) and various polysaccharide-peptide complexes, compounds which reduce cancer metastases and stimulate the production of interleukin-1 in human cells [18-20]. 
The abundant presence of free radicals in the environment is associated with the appearance of oxidative stress which is a basis of aging and the initiation and progress of various diseases and disorders from which a large part of the world's population suffers and dies [21]. DNA is more sensitive to oxidative damage than other macromolecules. DNA damage, such as strand breaks, could be induced by various agents among which $\mathrm{H}_{2} \mathrm{O}_{2}$ produces a genotoxic effect. It is known that those damages can affect the immune response not only in inflammatory diseases but also in cancers $[22,23]$. The comet test is a well-established and effective test of high sensitivity that has been used for examining DNA damage and can be applied to assess the genotoxic and protective potential of several natural products [24-26].

A genoprotective activity of mushroom extracts based on the reduction of oxidative damages of DNA can also play a significant role in prevention and treatment of several mentioned diseases and disorders but very few studies until nowadays considered it as a possible tool of action in different therapies $[27,28]$. Therefore the goal of the study was to evaluate antigenotoxic effects of mycelium and basidiocarp extracts of selected Trametes species on human peripheral white blood cells and to assess dependence on their antioxidant potential.

\section{Materials and Methods}

2.1. Organisms and Cultivation Conditions. Cultures of Trametes versicolor BEOFB 321, T. hirsuta BEOFB 301, and $T$. gibbosa BEOFB 310 were isolated from fruiting bodies collected from Serbia and maintained on Malt agar medium in the culture collection of the Institute of Botany, Faculty of Biology, University of Belgrade (BEOFB).

The inoculum was prepared by inoculation of $100.0 \mathrm{~mL}$ of synthetic medium (glucose, $10.0 \mathrm{~g} \mathrm{~L}^{-1} ; \mathrm{NH}_{4} \mathrm{NO}_{3}, 2.0 \mathrm{~g} \mathrm{~L}^{-1}$; $\mathrm{K}_{2} \mathrm{HPO}_{4}, 1.0 \mathrm{~g} \mathrm{~L}^{-1} ; \mathrm{NaH}_{2} \mathrm{PO}_{4} \times \mathrm{H}_{2} \mathrm{O}, 0.4 \mathrm{gL}^{-1} ; \mathrm{MgSO}_{4} \times$ $7 \mathrm{H}_{2} \mathrm{O}, 0.5 \mathrm{~g} \mathrm{~L}^{-1}$; yeast extract, $2.0 \mathrm{~g} \mathrm{~L}^{-1}$; $\left.\mathrm{pH} 6.5\right)$ with 25 mycelial disks ( $\varnothing 0.5 \mathrm{~cm}$, from 7-day-old culture from malt agar) in $250 \mathrm{~mL}$ flasks and incubation on a rotary shaker at $100 \mathrm{rpm}$, at room temperature $\left(22 \pm 2^{\circ} \mathrm{C}\right)$ for $7 \mathrm{~d}$. The resultant biomass was washed and homogenized with $100.0 \mathrm{~mL}$ of sterile distilled water $\left(\mathrm{dH}_{2} \mathrm{O}\right)$ in a laboratory blender. Homogenized biomass $(30.0 \mathrm{~mL})$ was used for inoculation of $500.0 \mathrm{~mL}$ modified synthetic medium (with glucose present at $\left.65.0 \mathrm{~g} \mathrm{~L}^{-1}\right)$. Submerged cultivation was carried out in $1000 \mathrm{~mL}$ flasks at room temperature on a rotary shaker for $21 \mathrm{~d}$. The obtained biomass was filtered, washed 3 times with $\mathrm{dH}_{2} \mathrm{O}$ on a magnetic stirrer, and dried at $50^{\circ} \mathrm{C}$ to constant weight.

2.2. Preparation of the Fungal Extracts. Dried fruiting body and mycelium $(3.0 \mathrm{~g})$ were extracted by stirring with $90.0 \mathrm{~mL}$ of $96 \%$ ethanol at $30^{\circ} \mathrm{C}$ for $72 \mathrm{~h}$. The resulting extracts were centrifuged $\left(20^{\circ} \mathrm{C}, 3000 \mathrm{rpm}, 15 \mathrm{~min}\right)$ and supernatants were filtered through Whatman number 4 filter paper, concentrated under reduced pressure in a rotary evaporator (BÜCHI $\mathrm{R}-114$, Switzerland) at $40^{\circ} \mathrm{C}$ to dryness, and redissolved in $96 \%$ ethanol for antioxidant assay [29] or water for antigenotoxic assay [30] to an initial concentration of $20.0 \mathrm{mg} \mathrm{mL}^{-1}$.
The extraction yield was expressed as percentage on a dry weight basis.

\subsection{Genoprotective Activity}

2.3.1. Subjects. Heparinized whole blood samples were obtained by venipuncture from three healthy donors aged under 25. Participants of the study were nonsmokers and nonalcoholics, not receiving any therapy or medications and not taking dietary supplements.

2.3.2. Study Design. Genotoxicity of all extracts and concentrations $\left(20.0,10.0,5.0,2.5,1.25,0.625\right.$, and $\left.0.312 \mathrm{mg} \mathrm{mL}^{-1}\right)$ was studied by treatment of human peripheral white blood cells at $37^{\circ} \mathrm{C}$ for $30 \mathrm{~min}$ with the aim of evaluating DNA damage. Normally, white blood cells are used, because they are obtained in a relatively noninvasive way, do not require tissue disaggregation, and behave well in the comet assay [31]. Treatment with phosphate buffered saline (PBS) at $37^{\circ} \mathrm{C}$ for 30 min was used as a positive control and treatment with $25.0 \mu \mathrm{M} \mathrm{H}_{2} \mathrm{O}_{2}$ on ice for $15 \mathrm{~min}$ as a negative control.

Two independent protocols were used to assess the antigenotoxic potential of extracts, using pretreatment and posttreatment with the extracts. In pretreatment, the cells were incubated with extracts at $37^{\circ} \mathrm{C}$ for $30 \mathrm{~min}$, then washed with PBS, and exposed to $\mathrm{H}_{2} \mathrm{O}_{2}$ for $15 \mathrm{~min}$. In posttreatment, the cells were treated with $\mathrm{H}_{2} \mathrm{O}_{2}$ on ice for $15 \mathrm{~min}$, rinsed with PBS, and subsequently treated with the seven extract concentrations at $37^{\circ} \mathrm{C}$ for $30 \mathrm{~min}$. After each treatment, the cells were washed with PBS. Incubation with PBS at $37^{\circ} \mathrm{C}$ for $30 \mathrm{~min}$ was the negative control and treatment with $25.0 \mu \mathrm{M}$ $\mathrm{H}_{2} \mathrm{O}_{2}$ on ice for 15 min represented the positive control.

Three replicates were performed for each experiment and 100 nuclei were analyzed for each.

2.3.3. The Single Cell Gel Electrophoresis Assay. The comet assay was performed as described by Singh et al. [32]. The alkaline comet test is able to detect DNA strand breaks and alkali-labile sites, and the extent of DNA migration indicates the degree of DNA damage in cells.

Whole blood samples $(6.0 \mu \mathrm{L})$ were suspended in $0.67 \%$ low-melting-point (LMP) agarose (Sigma-Aldrich, St. Louis, $\mathrm{MO}$ ) and pipetted onto superfrosted glass microscope slides precoated with a layer of $1 \%$ normal-melting-point agarose (Sigma-Aldrich, St. Louis, MO), spread using a cover slip, and maintained on ice for 5 min to solidify. After gently removing the cover slips, the cell suspensions on slides were treated with the extracts and $\mathrm{H}_{2} \mathrm{O}_{2}$ as described above. Following the treatments, all slides were covered with the third layer of $0.5 \%$ LMP agarose and again was allowed to solidify on ice for $5 \mathrm{~min}$. After removal of the cover slips, the slides were placed in cold lysing solution $(2.5 \mathrm{M} \mathrm{NaCl}, 100 \mathrm{mM}$ EDTA, $10 \mathrm{mM}$ Tris, 1\% Triton X100, and 10\% dimethyl sulfoxide, $\mathrm{pH} 10.0$ adjusted with $\mathrm{NaOH}$ ) at $4^{\circ} \mathrm{C}$ overnight and afterwards subjected to electrophoresis and staining with ethidium bromide [32]. The comets were observed and analyzed using an Olympus $\times 50$ microscope (Olympus Optical Co., Gmbh Hamburg, Germany), equipped with a device for recording fluorescence at $100 \mathrm{x}$ magnification. 


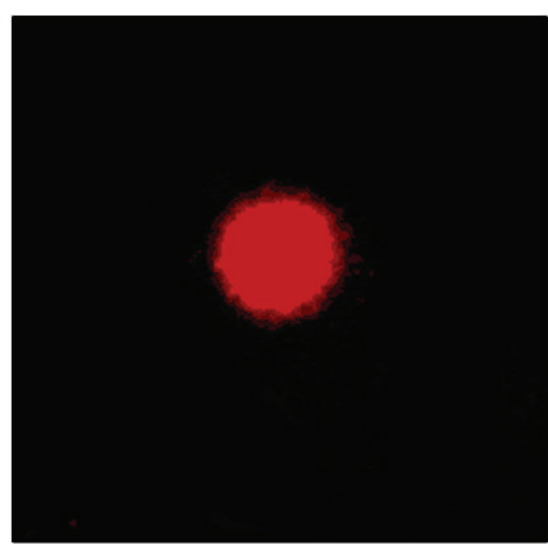

(a)

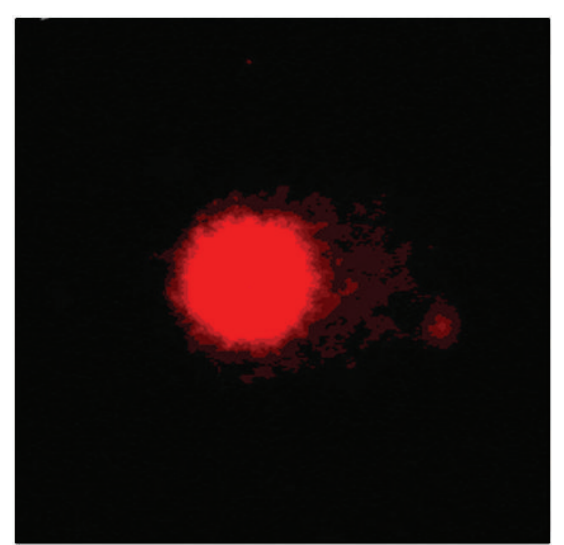

(b)

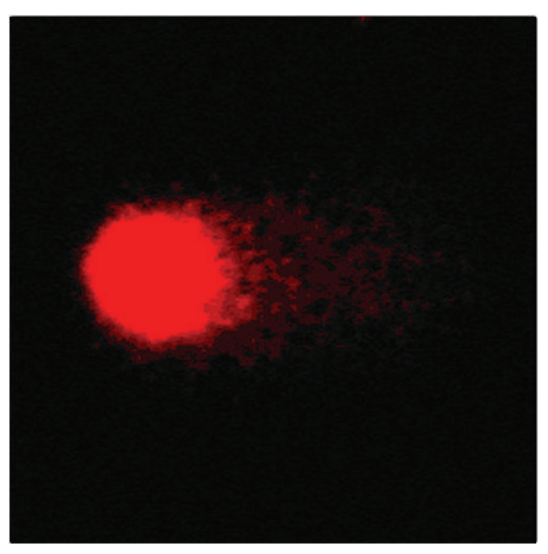

(c)

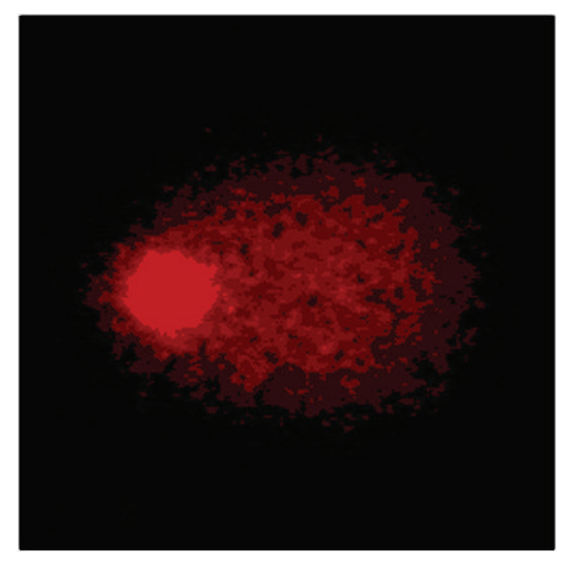

(d)

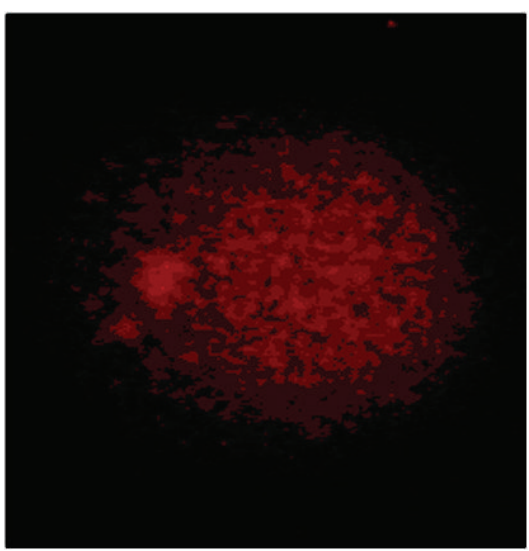

(e)

FIGURE 1: Categorisation of DNA damage corresponding to the amount of DNA in the tail.

Evaluation of DNA damage was performed as described by Anderson et al. [24]. Namely, cells were graded by eye into five categories corresponding to the following amounts of DNA in the tail: (A) no damage, <5\%; (B) low level damage, 5-20\%; (C) medium level damage, 20-40\%; (D) high level damage, 40-95\%; (E) total damage, $>95 \%$ (Figure 1). Analysis was performed on 100 randomly selected cells per subject (50 cells from each of 2 replicate slides). To obtain semiquantitative analysis of data, DNA damage was characterized as DNA migration over $5 \%(B+C+D+E$ comet classes $)$.

\subsection{Antioxidant Activity}

2.4.1. $\mathrm{DPPH}^{\circ}$ Assay. Antioxidant activity was defined by measuring bleaching of the purple-colored methanol solution of stable 1,1-diphenyl-2-picrylhydrazyl radical (DPPH*) [33]. Scavenging effects were measured spectrophotometrically (CECIL CE 2501) at $517 \mathrm{~nm}$ and calculated using the equation:

\section{$\mathrm{DPPH}^{\bullet}$ scavenging effect (\%)}

$$
=\left[\left(A_{0}-A_{\text {sample }}\right) A_{0}^{-1}\right] \times 100,
$$

where $A_{0}$ is absorbance of the negative control (reaction mixture without extract) and $A_{\text {sample }}$ is absorbance of reaction mixture.
Extract concentration (mg extract $/ \mathrm{mL}$ ) providing $50 \%$ of $\mathrm{DPPH}^{\bullet}$ reduction $\left(\mathrm{EC}_{50}\right)$ was obtained by interpolation from linear regression analysis. All the measurements were carried out in triplicate for statistical analysis. Commercial antioxidant, butylated hydroxyanisole (BHA), in a concentration range of $20.0 \mathrm{mg} \mathrm{mL}^{-1}-0.02 \mathrm{mg} \mathrm{mL}^{-1}$, was used as a positive control.

2.4.2. Determination of Total Phenol Content. Total phenol compounds in the mycelial extracts were estimated with Folin-Ciocalteu reagent according to the method of Singleton and Rossi [34], using gallic acid as a standard. The concentration was determined as $\mu \mathrm{g}$ of gallic acid equivalents (GAE) per mg of dry extract, using an equation that was obtained from a standard gallic acid graph as

Absorbance $=0.012$

$$
\begin{aligned}
& \times \text { total phenols }(\mu \mathrm{g} \text { of gallic acid }) \\
& -0.029\left(R^{2}=0.999\right)
\end{aligned}
$$

2.4.3. Determination of Total Flavonoid Content. Total flavonoid content was determined by the methods of Park et al. [35] using quercetin as the standard. The amount was 
expressed as $\mu \mathrm{g}$ of quercetin equivalents (QE) per $\mathrm{mg}$ of dry extract, using an equation obtained from a standard quercetin hydrate graph as

$$
\begin{aligned}
& \text { Absorbance } \\
& =0.011 \\
& \times \text { total flavonoids ( } \mu \text { g of quercetin hydrate) } \\
& +0.080\left(R^{2}=1.0\right) \text {. }
\end{aligned}
$$

2.5. Statistical Analysis. The results were expressed as the mean \pm standard error of data obtained from three parallel measurements. One-way analysis of variance (ANOVA) was performed using STATISTIKA software, version 5.0 (StatSoft Inc.) to test any significant differences. $P$ values less than 0.01 were considered statistically significant. The statistical analysis of data from the comet assay was performed by $\chi^{2}$ test using Statgraph 4.2 software. To perform $\chi^{2}$ test, results from the three experiments were pooled and we evaluated total number of cells with DNA damages. A difference at $P<0.05$ was considered statistically significant.

\section{Results and Discussion}

3.1. Extraction Yield. Extraction yields of mycelium biomass for all three species were significantly higher compared with the fruiting body $(P<0.01)$. T. gibbosa had the highest extraction yield from dried mycelium biomass (34.6\%) and the lowest yield from dried fruiting bodies (2.2\%). The highest fruiting body extraction yield of $6.67 \%$ was found in $T$. versicolor, whose mycelium extraction yield was $8.0 \%$. Yields in T. hirsuta were $12.0 \%$ (for mycelium) and $2.85 \%$ (for fruiting body). Differences in extraction efficiency among the species, for both mycelium and fruiting body, were statistically significant $(P<0.01)$.

Previous reports showed the dependence of biomass extractability on species, strain, and solvent [36-38]. Thus, Ren et al. [37] found that extraction yields of T. gibbosa basidiocarp were $1.22 \%$ for petroleum ether extract, $6.44 \%$ for ethyl acetate, and 9.2\% for methanol extracts. Methanol was also a good solvent for T. versicolor basidiocarp whose yield ranged between $4.1 \%$ and $9.16 \%[36,38]$. Based on our results, it can be concluded that alcohols are the best solvents, but ethanol is weaker than methanol.

3.2. Genoprotective Activity. As all blood donors were of good health and similar age and under no medication, the statistical analysis showed no clear differences in their responses to extracts. Therefore, results from the three experiments were pooled. Treatment of peripheral blood leukocytes with $\mathrm{H}_{2} \mathrm{O}_{2}$ caused a quick and powerful induction of single strand breaks in the nuclear DNA, which was visible in the comet assay as DNA migration.

Our results demonstrated that $T$. versicolor fruiting body extracts from 0.312 to $20.0 \mathrm{mg} \mathrm{mL}^{-1}$ caused no significant increase in the total number of DNA-damaged cells compared with the positive control, which clearly shows that the tested extract was not a genotoxic agent (Figure 2(a) (A)). The distribution (value) of total DNA damage was also the same as in the positive control. On the other hand, these extracts showed protective effects against $\mathrm{H}_{2} \mathrm{O}_{2}$ both in pre- and posttreatment of leukocytes (Figure $2(\mathrm{a})(\mathrm{B}, \mathrm{C})$ ). The extract at $5.0 \mathrm{mg} \mathrm{mL}^{-1}$ had the greatest effect and at $20.0 \mathrm{mg} \mathrm{mL}^{-1}$ the lowest effect in both treatments. The value of total DNA damage statistically decreased compared with the positive control in all concentrations $(P<0.05)$.

T. hirsuta fruiting body extract at all concentrations except $20.0 \mathrm{mg} \mathrm{mL}^{-1}$ showed no genotoxic activity as the level of total DNA damage was not statistically higher than that in the positive control (Figure 2(b) (A)). However, at a concentration of $20.0 \mathrm{mg} \mathrm{mL}^{-1}$, the genotoxic effect and total DNA damage in cells were statistically different compared with the positive control. In pre- and posttreatments of leukocytes, the extract at all concentrations except the highest one exhibited a protective effect against $\mathrm{H}_{2} \mathrm{O}_{2}$-induced DNA damage, showing significant decrease of total DNA damage compared with the positive control (Figure 2(b) $(B, C)$ ). These treatments displayed a dose-dependent correlation, with the greatest protective effect at an extract concentration of $0.312 \mathrm{mg} \mathrm{mL}^{-1}$ while the concentration of $20 \mathrm{mg} \mathrm{mL}^{-1}$ showed no protection against comets induced by $\mathrm{H}_{2} \mathrm{O}_{2}$.

The absence of a genotoxic as well as significant antigenotoxic effect, that is, reduction of DNA damage induced by $\mathrm{H}_{2} \mathrm{O}_{2}$, in both pre- and posttreatment, was also noted for T. gibbosa fruiting body extract at the seven concentrations (Figure 2(c)). However, contrary to T. hirsuta extracts, a dose-dependent response was not observed in $T$. gibbosa basidiocarp extracts; namely, a gradual decrease of extract concentration did not correspond with a proportional reduction of $\mathrm{H}_{2} \mathrm{O}_{2}$-induced genotoxicity.

The mycelium extracts of $T$. versicolor, T. hirsuta, and T. gibbosa, at all analyzed concentrations, had no genotoxic activity (Figures 3(a) (A), 3(b) (A), and 3(c) (A)). All mycelium extracts and concentrations showed a significant antigenotoxic effect against the $\mathrm{H}_{2} \mathrm{O}_{2}$-induced DNA damage, both in pre- and posttreatment, and these activities were not markedly different. In T. versicolor, a slightly lower activity was noted at the lowest extract concentration. In T. hirsuta, concentrations of $5.0,2.5$, and $20.0 \mathrm{mg} \mathrm{mL}^{-1}$ were more effective, while in T. gibbosa the greatest protective effect was observed at a concentration of $2.5 \mathrm{mg} \mathrm{mL}^{-1}$ and the lowest one at $20.0 \mathrm{mg} \mathrm{mL}^{-1}$ (Figures 3(a) (B, C), 3(b) (B, C), and 3(c) $(\mathrm{B}, \mathrm{C}))$.

Numerous mutagenic and carcinogenic compounds are present in different natural sources [39]. On the other hand, some natural compounds could be either prooxidants causing genotoxic and/or cytotoxic effects or antioxidants, depending on the concentration and duration of exposure [4043]. Highly nutritional and medicinally valued mushroom species may have different in vitro and in vivo effects due to either their instability under digestion conditions or inability of absorption by the gastrointestinal tract [44]. Namely, activities obtained in vitro do not necessarily correspond to those found in vivo. It is also important to emphasize that genotoxic and antigenotoxic effects of mushroom extracts 


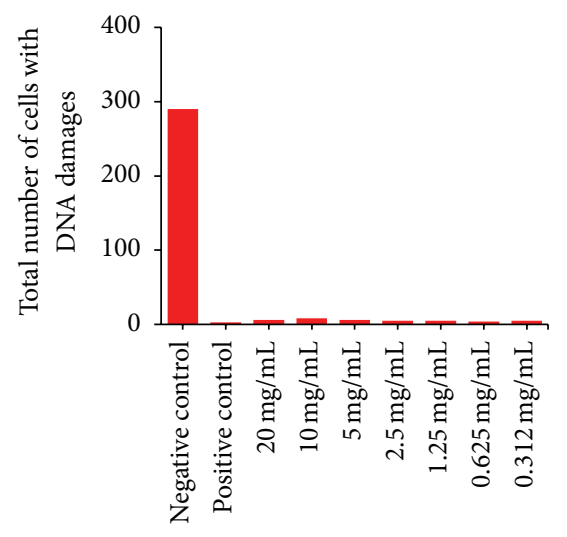

${ }^{*}<0.05$ versus positive control

(A)

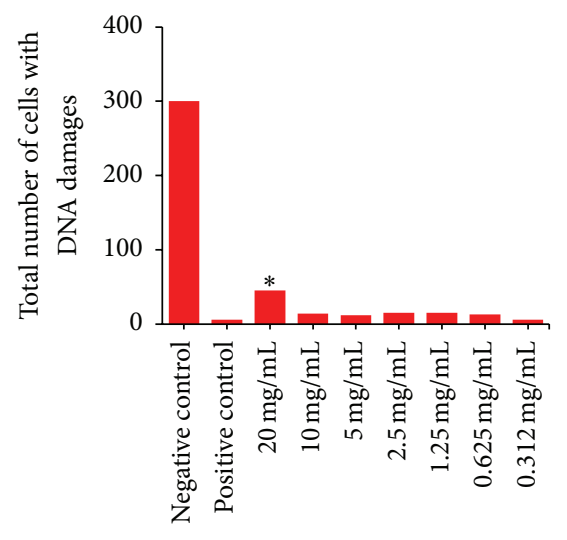

${ }^{*}<0.05$ versus positive control

(A)

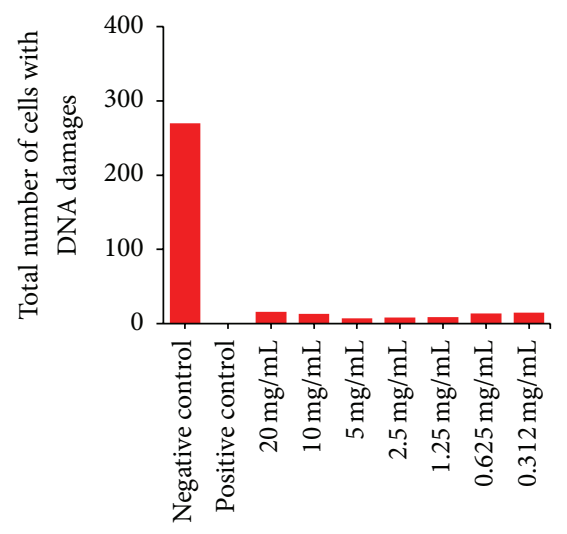

${ }^{*}<0.05$ versus positive control

(A)

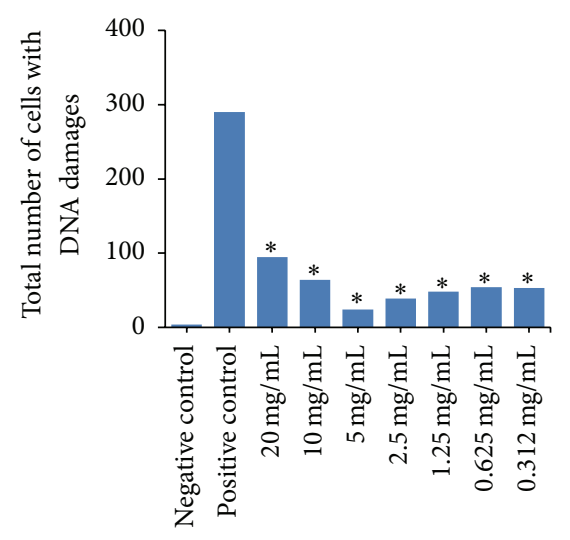

${ }^{*}<0.05$ versus positive control

(B)

(a)

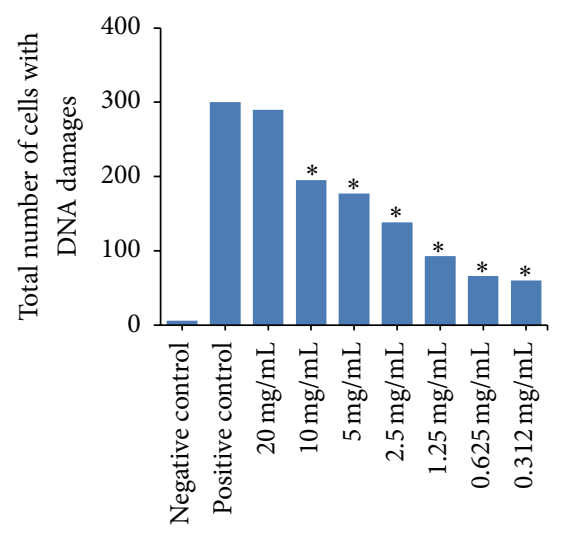

${ }^{*}<0.05$ versus positive control

(B)

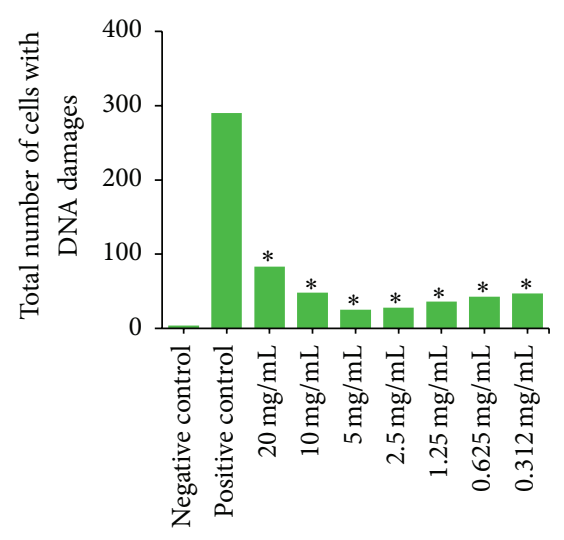

${ }^{*}<0.05$ versus positive control

(C)

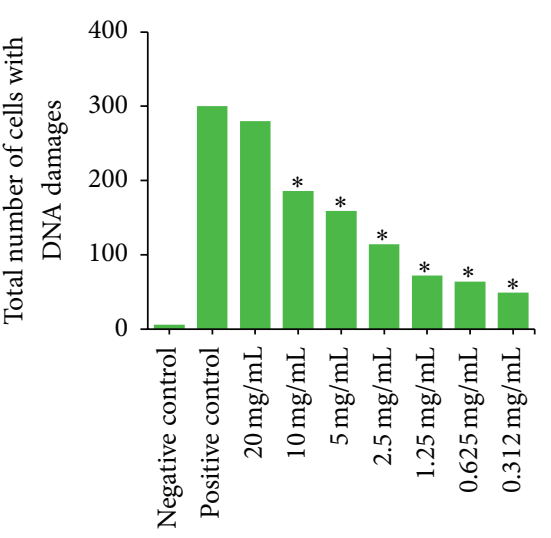

${ }^{*}<0.05$ versus positive control

(C)

(b)

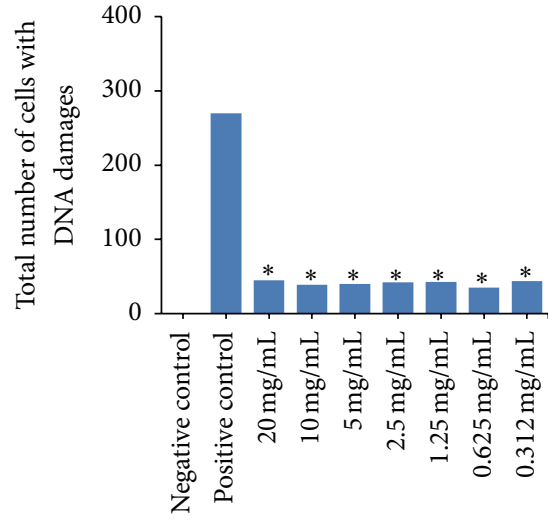

${ }^{*}<0.05$ versus positive control

(B)

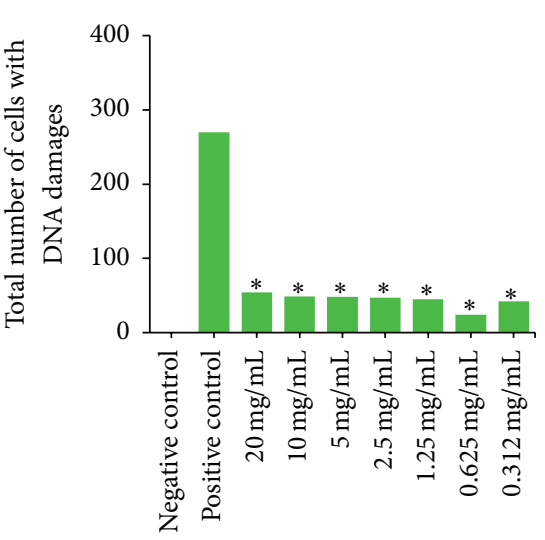

${ }^{*}<0.05$ versus positive control

(C)

(c)

FIGURE 2: Effect of fruiting body extracts of (a) Trametes versicolor, (b) T. hirsuta, and (c) T. gibbosa: (A) genotoxic, (B) antigenotoxic, pretreatment, and (C) antigenotoxic, posttreatment. Three independent experiments with three replicates per experiment were done and evaluated by comet assay. 100 nuclei per each replicate were analyzed. Data represent total number of cells with DNA damage. 


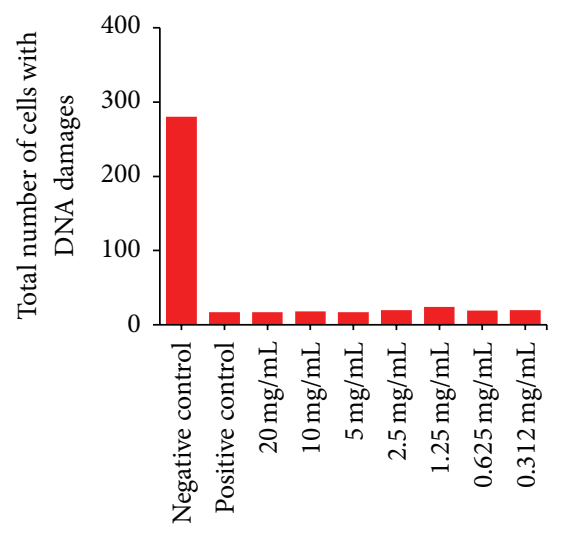

${ }^{*}<0.05$ versus positive control

(A)

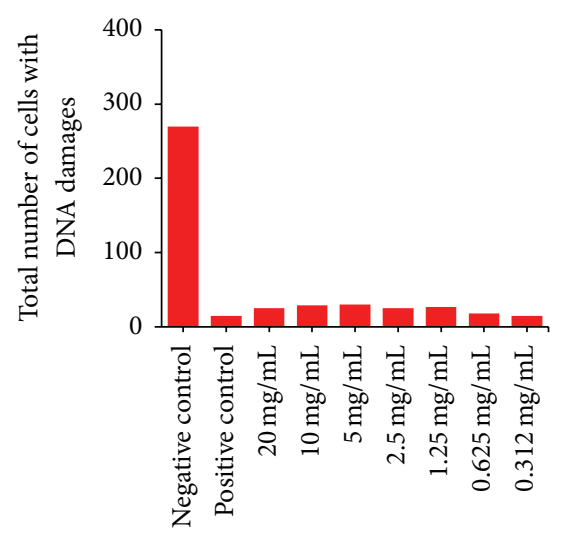

${ }^{*}<0.05$ versus positive control

(A)

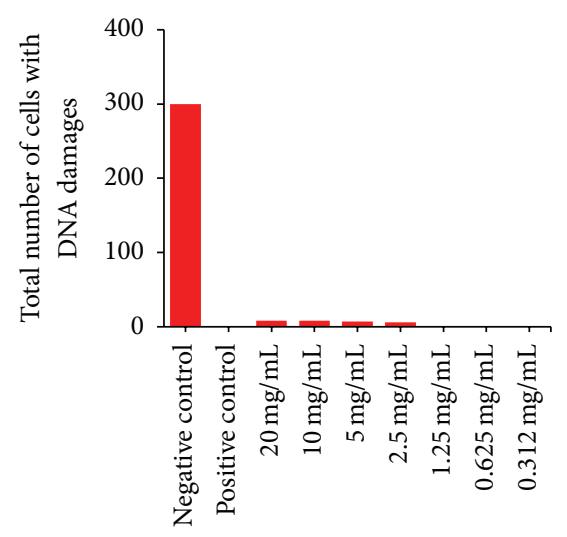

${ }^{*}<0.05$ versus positive control

(A)

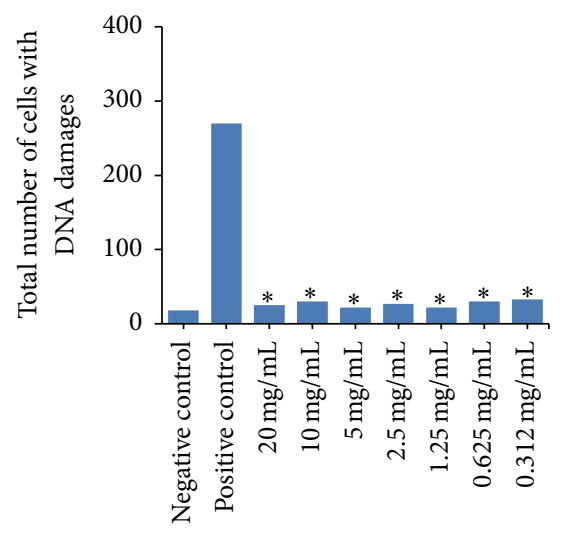

${ }^{*}<0.05$ versus positive control

(B)

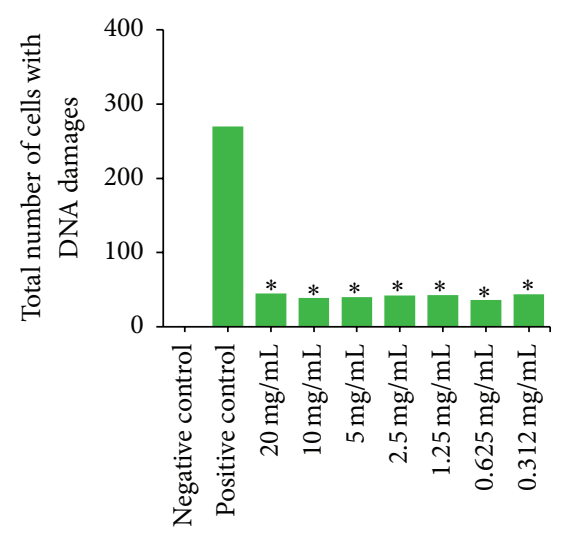

${ }^{*}<0.05$ versus positive control

(C)

(a)

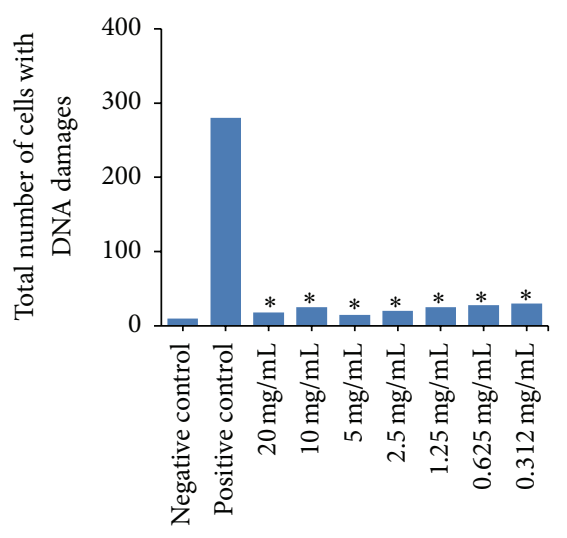

${ }^{*}<0.05$ versus positive control

(B)

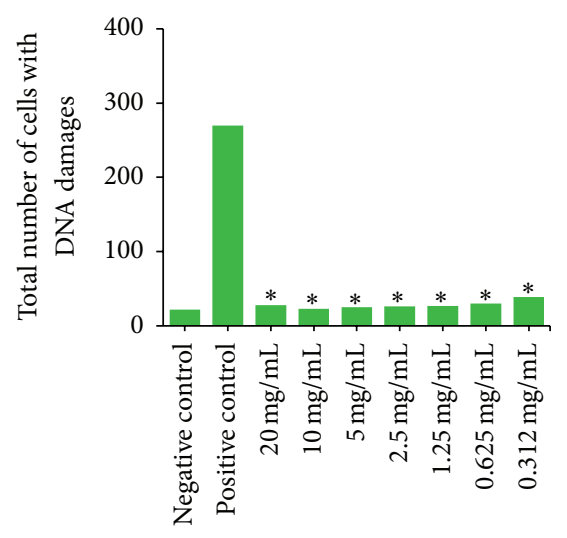

${ }^{*}<0.05$ versus positive control

(C)

(b)

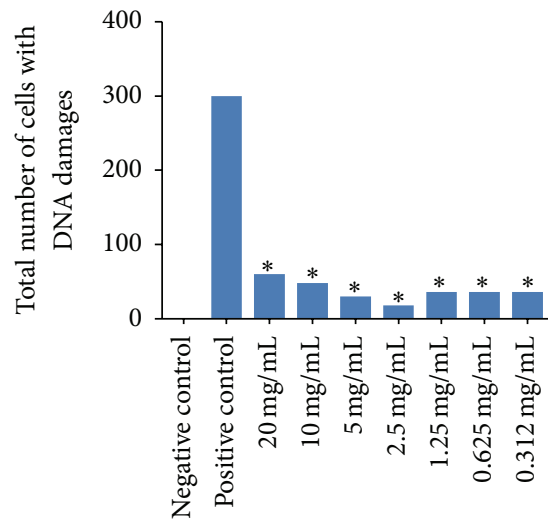

${ }^{*}<0.05$ versus positive control

(B)

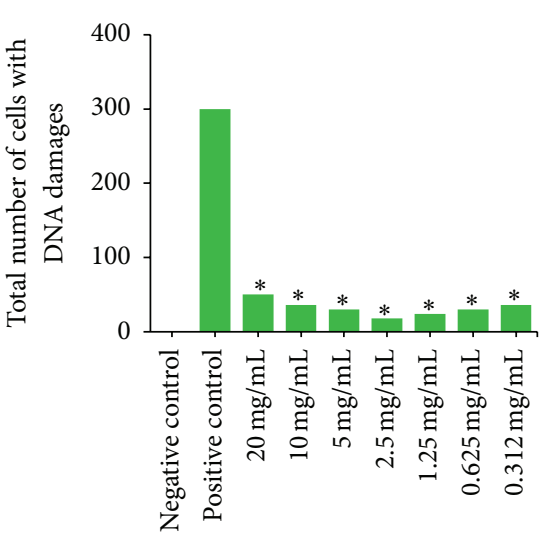

${ }^{*}<0.05$ versus positive control

(C)

(c)

Figure 3: Effect of mycelium extracts of (a) Trametes versicolor, (b) T. hirsuta, and (c) T. gibbosa: (A) genotoxic, (B) antigenotoxic, pretreatment, and (C) antigenotoxic, posttreatment. Three independent experiments with three replicates per experiment were done and evaluated by comet assay. 100 nuclei per each replicate were analyzed. Data represent total number of cells with DNA damage. 
TABLE 1: Total phenol and flavonoid content in ethanolic extracts of selected Trametes species.

\begin{tabular}{lccc}
\hline Tested species & Extract & $\begin{array}{c}\text { Total phenol content } \\
(\mu \mathrm{g} \mathrm{GAE} / \mathrm{mg} \text { of dried extract })\end{array}$ & $\begin{array}{r}\text { Total flavonoid content } \\
(\mu \mathrm{g} \text { QE/mg of dried extract })\end{array}$ \\
\hline Trametes gibbosa & Basidiocarp & $20.07 \pm 1.24$ & $7.63 \pm 0.08$ \\
& Mycelium & $12.08 \pm 0.87$ & $1.76 \pm 0.03$ \\
\hline \multirow{2}{*}{ Trametes hirsuta } & Basidiocarp & $21.53 \pm 2.36$ & $8.28 \pm 0.05$ \\
\hline \multirow{2}{*}{ Trametes versicolor } & Mycelium & $14.27 \pm 0.92$ & $2.21 \pm 0.02$ \\
\hline
\end{tabular}

depend on species, concentration, and the assay used for their assessment [44-47]. Thus, our results demonstrated different capacities of the three Trametes species for decreasing $\mathrm{H}_{2} \mathrm{O}_{2}$ induced DNA damage; for example, the lowest activity was noted in fruiting body extract of T. hirsuta. A clear inverse dose-response relationship between the level of DNA damage and extract concentration was noted only in T. hirsuta basidiocarp extract. However, in T. versicolor and T. gibbosa, increasing the extract concentration above the optimal dose did not lead to any improvement in comet results which confirms results of Miyaji et al. [40]. These authors showed the absence of a dose-response relationship between Lentinus edodes extract concentrations and their antigenotoxic effect. It is important to mention that combined phenolic, flavonoid, and other ingredients in extracts should have greater potential than individual components of extracts, indicating the significance of coactions of all ingredients [48]. That finding could result in different trend of Trametes spp. antigenotoxic activity. Dependence of the genotoxic activity of the extract on the assay type was demonstrated by Morales et al. [47]; that is, they reported absence of mutagenic effect of basidiocarp extracts of Lactarius deliciosus, Boletus luteus, Agaricus bisporus, and Pleurotus ostreatus on mammalian cells using the Ames Salmonella/microsome test. However, a weak activity of $P$. ostreatus extract was obtained using the $\mathrm{CHO} / \mathrm{HPRT}$ assay.

The underlying mechanisms of the antigenotoxic effect of mushroom extracts are still not completely known. Protective effects of the extracts seem to be based on more than one mechanism of action, which is not uncommon for mushrooms according to Gebhart [49]. The antigenotoxicity mechanisms could be evaluated by applications of pre- and posttreatments, that is, diverse combinations of extracts and $\mathrm{H}_{2} \mathrm{O}_{2}$. Our positive results in both treatments indicate that extracts have protective effects at both the prevention and intervention levels and may act as desmutagens and bioantimutagens, also demonstrated by previous studies [5052]. Efficiency of pretreatment, noted in the present study, could be explained by increasing the antioxidant capacity of cells, that is, stimulating the synthesis and activity of antioxidant enzymes during the induction of oxidative stress [53]. The positive effect of posttreatment could be the result of synergistic action of interventional activities via free radical scavenging and stimulation of antioxidant enzymes, as well as excitation of DNA repair, as suggested by Chiaramonte et al. [54]. As these authors reported significant DNA damage repair after 30-60 min of exposure to an oxidative agent, it could be concluded that DNA repair played a less significant role in protection against $\mathrm{H}_{2} \mathrm{O}_{2}$ since posttreatment conditions considered up to $30 \mathrm{~min}$ of incubation. Therefore, the genoprotective activity of the Trametes spp. extracts is probably based on antioxidant actions. On the other hand, it is known that eukaryotic organisms have evolved a signaling pathway, called the DNA damage response, to protect against genomic insults. Gasser and Raulet [22] demonstrated that the DNA damage response alerts the immune system by inducing expression of cell surface ligands for the activating immune receptor NKG2D, which is expressed by natural killer cells (NK cells) and some $\mathrm{T}$ cells. Therefore, the genoprotective activity of Trametes spp. in the cells exposed to genotoxic agents could modulate DNA damage response and function as a barrier in early tumorigenesis. The further researches should include analysis of superoxide dismutase and catalase levels in lymphocytes treated with Trametes spp. extracts, both in pre- and posttreatment with $\mathrm{H}_{2} \mathrm{O}_{2}$, in order to confirm assumption that enhancement of antioxidant capacity in cells is induced by those extracts.

3.3. Antioxidant Activity. The tested ethanol extracts were good antioxidants but their activity depended on species. Fruiting body extracts showed significantly higher scavenging effects than mycelium extracts $(P<0.01)$. The highest DPPH radical scavenging activity was detected in T. versicolor extracts, both fruiting body and mycelium (63.5\% and 59.4\%, resp.) which was confirmed by $\mathrm{EC}_{50}$ values $\left(15.22 \mathrm{mg} \mathrm{mL}^{-1}\right.$ and $16.18 \mathrm{mg} \mathrm{mL}^{-1}$, resp.). A slightly lower level of activity was found for T. hirsuta extracts (59.0\% for basidiocarps and $46.8 \%$ for mycelium), whose concentrations of $17.06 \mathrm{mg} \mathrm{mL}^{-1}$ and $21.81 \mathrm{mg} \mathrm{mL}^{-1}$, respectively, provided a $50 \%$ reduction of radicals. T. gibbosa was the species with the lowest $\mathrm{DPPH}^{*}$ scavenging potential, especially of mycelium extracts (39.7\%) with $\mathrm{EC}_{50}$ value of $26.15 \mathrm{mg} \mathrm{mL}^{-1}$. However, the radical scavenging ability of the fruiting body extract was not significantly lower in comparison with the other two species (53.7\% and $\mathrm{EC}_{50}$ of $18.13 \mathrm{mg} \mathrm{mL}^{-1}$ ). The $\mathrm{DPPH}^{*}$ scavenging activity of synthetic antioxidant BHA was $94.28 \%$, and a concentration of $0.10 \mathrm{mg} \mathrm{mL}^{-1}$ provided $\mathrm{DPPH}^{*}$ reduction of $50 \%$.

Total phenol contents in fruiting body and mycelium extracts of Trametes species were significantly different $(P<$ 0.01) (Table 1). Generally, phenol contents in fruiting body extracts were higher than in mycelium extracts.

Both T. versicolor basidiocarp and T. versicolor mycelium extracts were the richest with phenols and flavonoids, while 
the lowest concentrations were measured in T. gibbosa extracts. According to the phenol and flavonoid concentrations, extracts of T. hirsuta came between the other two species extracts (Table 1). The degree of correlation between the $\mathrm{DPPH}^{*}$ scavenging activity of the extracts and phenol and flavonoid contents was high with $R^{2}$ for fruiting bodies of 0.98 and 0.99 , respectively, and for mycelium of 0.97 and 0.99 , respectively.

Previous studies have also indicated the antioxidant potential of Trametes species [17, 55, 56]. Thus, Kamiyama et al. [56] demonstrated that an extract concentration of even $0.5 \mathrm{mg} \mathrm{mL}^{-1}$ scavenged nearly $50 \%$ of $\mathrm{DPPH}^{*}$ depending on the solvent, while Johnsy and Kaviyarasana [55] noted reduction of even $91.5 \%$ radicals by a methanol extract of T. gibbosa basidiocarps at a concentration of $1.0 \mathrm{mg} \mathrm{mL}^{-1}$. Ethanol extracts tested in our study had slightly lower capacities, but higher than ethanol T. hirsuta fruiting body extracts analyzed by Sheikh et al. [17].

According to Mau et al. [57] and Palacios et al. [58], phenolic compounds play a key role in antioxidative activity. These compounds are very abundant and important constituents of mushroom fruiting bodies and mycelia. Their ability is based on the presence of hydroxyl groups acting as reducing agents, metal chelators, singlet oxygen quenchers, and hydrogen donors [59]. However, in some cases their activity could not be attributed to the total phenol content in extracts, which is confirmed by comparison of our results with those of Johnsy and Kaviyarasana [55]. Namely, 91.5\% of $\mathrm{DPPH}^{\circ}$ was reduced by T. gibbosa basidiocarp extract

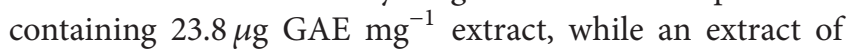
strain BEOFB 310 with a phenol concentration of $20.07 \mu \mathrm{g}$ GAE $\mathrm{mg}^{-1}$ extract scavenged only $63.5 \%$ radicals. However, the concentration of flavonoids in the Serbian T. gibbosa strain was significantly higher compared with the strain tested by Johnsy and Kaviyarasana [55] (7.63 $\mu \mathrm{g} \mathrm{QE} \mathrm{mg}^{-1}$ of extract and $0.59 \mu \mathrm{g} \mathrm{QE} \mathrm{mg}{ }^{-1}$ of extract, resp.), and this could be explained by the various polarities of solvents as well as different strain capacity for flavonoid synthesis [60].

\section{Conclusion}

The study was the first attempt to assess the DNA protective activity of T. versicolor, T. hirsuta, and T. gibbosa extracts and determines whether this was based on their antioxidant potential. The results suggest that extracts of these three species could be considered as strong antigenotoxic agents able to stimulate genoprotective response of cells contributing to enhanced immune function, toxin removal, and strengthening, which refers to the traditional use. However, further investigations are necessary to reveal specific carriers of the antigenotoxic activity and the mode of DNA protection from oxidative damage.

\section{Conflict of Interests}

The authors declare that they have no conflict of interests regarding the publication of this paper.

\section{Acknowledgments}

The authors thank Professor Dr. Steve Quarrie, Visiting Professor at the University of Newcastle, UK, for revising and improving English. This study was carried out with financial support of the Ministry of Education, Science, and Technological Development of Republic of Serbia, Project no. 173032 and Project no. 173034.

\section{References}

[1] P. Roupas, J. Keogh, M. Noakes, C. Margetts, and P. Taylor, “The role of edible mushrooms in health: evaluation of the evidence," Journal of Functional Foods, vol. 4, no. 4, pp. 687-709, 2012.

[2] P. Manzi, L. Gambelli, S. Marconi, V. Vivanti, and L. Pizzoferrato, "Nutrients in edible mushrooms: an inter-species comparative study," Food Chemistry, vol. 65, no. 4, pp. 477-482, 1999.

[3] L. Barros, B. A. Venturini, P. Baptista, L. M. Estevinho, and I. C. F. R. Ferreira, "Chemical composition and biological properties of Portuguese wild mushrooms: a comprehensive study," Journal of Agricultural and Food Chemistry, vol. 56, no. 10, pp. 3856-3862, 2008.

[4] S. P. Wasser, "Review of medicinal mushrooms advances: good news from old allies," HerbalGram, vol. 56, pp. 28-33, 2002.

[5] I. V. Zmitrovich, O. N. Ezhov, and S. P. Wasser, "A survey of species of genus Trametes Fr. (higher basidiomycetes) with estimation of their medicinal source potential," International Journal of Medicinal Mushrooms, vol. 14, no. 3, pp. 307-319, 2012.

[6] C. Hobbs, Medicinal Mushrooms: An Exploration of Tradition, Healing and Culture, Botanica Press, Santa Cruz, Calif, USA, 1995.

[7] K. K. W. Chu, S. S. S. Ho, and A. H. L. Chow, "Coriolus versicolor: a medicinal mushroom with promising immunotherapeutic values," Journal of Clinical Pharmacology, vol. 42, no. 9, pp. 976984, 2002.

[8] J. M. F. Wan, Handbook of Biologically Active Peptides, Academic Press, Baton Rouge, La, USA, 2006.

[9] Q. Y. Yang, Y. J. Hu, X. Y. Li et al., Proceedings of PSP International Symposium, Fudan University Press, Shanghai, China, 1996.

[10] T. B. Ng, "A review of research on the protein-bound polysaccharide (polysaccharopeptide, PSP) from the mushroom Coriolus versicolor (basidiomycetes: polyporaceae)," General Pharmacology, vol. 30, no. 1, pp. 1-4, 1998.

[11] J. Cui and Y. Chisti, "Polysaccharopeptides of Coriolus versicolor: physiological activity, uses, and production," Biotechnology Advances, vol. 21, no. 2, pp. 109-122, 2003.

[12] A. Ming, Chinese-English Manual of Common-Used in Traditional Chinese Medicine, Publishing House of Guangdong Science \& Technology, Guangdong, China, 1996.

[13] U. Lindequist, T. H. J. Niedermeyer, and W.-D. Jülich, "The pharmacological potential of mushrooms," Evidence-Based Complementary and Alternative Medicine, vol. 2, no. 3, pp. 285299, 2005.

[14] L. J. Standish, C. A. Wenner, E. S. Sweet et al., "Trametes versicolor mushroom immune therapy in breast cancer," Journal of the Society for Integrative Oncology, vol. 6, no. 3, pp. 122-128, 2008. 
[15] R. A. Collins and T. B. Ng, "Polysaccharopeptide from Coriolus versicolor has potential for use against human immunodeficiency virus type 1 infection," Life Sciences, vol. 60, no. 25, pp. PL383-PL387, 1997.

[16] M. Stajić, J. Vukojević, A. Knežević, S. D. Laušević, and I. Milovanović, "Antioxidant protective effects of mushroom metabolites," Current Topics in Medicinal Chemistry, vol. 13, no. 21, pp. 2660-2676, 2013.

[17] I. A. Sheikh, D. Vyas, M. A. Ganaie, K. Dehariya, and V. Singh, "HPLC determination of phenolics and free radical scavenging activity of ethanolic extracts of two polypore mushrooms," International Journal of Pharmacy and Pharmaceutical Sciences, vol. 6, no. 2, pp. 679-684, 2014.

[18] H. Sakagami, K. Sugaya, A. Utsumi, S. Fujinaga, T. Sato, and M. Takeda, "Stimulation by PSK of interleukin-1 production by human peripheral blood mononuclear cells," Anticancer Research, vol. 13, no. 3, pp. 671-675, 1993.

[19] H. K. Kobayashi, K. Matsunaga, and Y. Oguchi, "Antimetastatic effects of PSK (Krestin), a protein-bound polysaccharide obtained from basidiomycetes: an overview," Cancer Epidemiology Biomarkers \& Prevention, vol. 4, no. 3, pp. 275-281, 1995.

[20] S. P. Wasser, "Medicinal mushroom science: history, current status, future trends and unsolved problems," International Journal of Medicinal Mushrooms, vol. 12, no. 1, pp. 1-16, 2010.

[21] J. Limón-Pacheco and M. E. Gonsebatt, "The role of antioxidants and antioxidant-related enzymes in protective responses to environmentally induced oxidative stress," Mutation Research/Genetic Toxicology and Environmental Mutagenesis, vol. 674, no. 1-2, pp. 137-147, 2009.

[22] S. Gasser and D. Raulet, "The DNA damage response, immunity and cancer," Seminars in Cancer Biology, vol. 16, no. 5, pp. 344$347,2006$.

[23] D. Menendez, M. Shatz, K. Azzam, S. Garantziotis, M. B. Fessler, and M. A. Resnick, "The toll-like receptor gene family is integrated into human DNA damage and p53 networks," PLoS Genetics, vol. 7, no. 3, Article ID e1001360, 2011.

[24] D. Anderson, T.-W. Yu, B. J. Phillips, and P. Schmezer, “The effect of various antioxidants and other modifying agents on oxygenradical-generated DNA damage in human lymphocytes in the COMET assay," Mutation Research, vol. 307, no. 1, pp. 261-271, 1994.

[25] D. W. Fairbairn, P. L. Olive, and K. L. O’Neill, “The comet assay: a comprehensive review," Mutation Research, vol. 339, no. 1, pp. 37-59, 1995.

[26] L. Henderson, A. Wolfreys, J. Fedyk, C. Bourner, and S. Windebank, "The ability of the Comet assay to discriminate between genotoxins and cytotoxins," Mutagenesis, vol. 13, no. 1, pp. 89-94, 1998.

[27] Y. Shi, A. E. James, I. F. F. Benzie, and J. A. Buswell, "Genoprotective activity of edible and medicinal mushroom components," International Journal of Medicinal Mushrooms, vol. 6, pp. 1-14, 2004.

[28] G. Aviello, J. M. Canadanovic-Brunet, N. Milic et al., "Potent antioxidant and genoprotective effects of boeravinone $\mathrm{G}$, a rotenoid isolated from Boerhaavia diffusa," PLoS ONE, vol. 6, no. 5, Article ID e19628, 2011.

[29] J. Ćilerdžić, J. Vukojević, M. Stajić, T. Stanojković, and J. Glamočlija, "Effect of substrate on antimicrobial, antioxidant and anticancer potential of Ganoderma lucidum basidiocarp extracts," Journal of Ethnopharmacology, vol. 155, pp. 312-319, 2014.
[30] L. F. Barbisan, C. Scolastici, M. Miyamoto et al., "Effects of crude extracts of Agaricus blazei on DNA damage and on rat liver carcinogenesis induced by diethylnitrosamine," Genetics and Molecular Research, vol. 2, no. 3, pp. 295-308, 2003.

[31] A. R. Collins, "The comet assay for DNA damage and repair: principles, applications, and limitations," Molecular Biotechnology, vol. 26, no. 3, pp. 249-261, 2004.

[32] N. P. Singh, M. T. McCoy, R. R. Tice, and E. L. Schneider, "A simple technique for quantitation of low levels of DNA damage in individual cells," Experimental Cell Research, vol. 175, no. 1, pp. 184-191, 1988.

[33] M. S. Blois, "Antioxidant determinations by the use of a stable free radical," Nature, vol. 181, no. 4617, pp. 1199-1200, 1958.

[34] V. L. Singleton and J. A. Rossi, "Colorimetry of total phenolics with phosphomolybdic-phosphotungistic acid reagents," American Journal of Enology and Viticulture, vol. 16, pp. 144-158, 1965.

[35] Y. K. Park, M. H. Koo, M. Ikegaki, and J. L. Contado, “Comparison of the flavonoid aglycone content of Apis mellifera propolisfrom various regions of Brazil," Arquivos de Biologiae Tecnologi, vol. 40, pp. 97-106, 1997.

[36] J.-L. Mau, H.-C. Lin, and C.-C. Chen, "Antioxidant properties of several medicinal mushrooms," Journal of Agricultural and Food Chemistry, vol. 50, no. 21, pp. 6072-6077, 2002.

[37] G. Ren, X. Y. Liu, H. K. Zhu, S. Z. Yang, and C. X. Fu, "Evaluation of cytotoxic activities of some medicinal polypore fungi from China," Fitoterapia, vol. 77, no. 5, pp. 408-410, 2006.

[38] M. Karaman, E. Jovin, R. Malbaša, M. Matavuly, and M. Popović, "Medicinal and edible lignicolous fungi as natural sources of antioxidative and antibacterial agents," Phytotherapy Research, vol. 24, no. 10, pp. 1473-1481, 2010.

[39] B. N. Ames, "Dietary carcinogens and anticarcinogens. Oxygen radicals and degenerative diseases," Science, vol. 221, no. 4617, pp. 1256-1263, 1983.

[40] C. K. Miyaji, B. Q. Jordão, L. R. Ribeiro, A. F. Eira, and I. M. S. Cólus, "Genotoxicity and antigenotoxicity assessment of shiitake (Lentinula edodes (Berkeley) Pegler) using the Comet assay," Genetics and Molecular Biology, vol. 27, no. 1, pp. 108-114, 2004.

[41] L. Nousis, P.-T. Doulias, N. Aligiannis et al., "DNA protecting and genotoxic effects of olive oil related components in cells exposed to hydrogen peroxide," Free Radical Research, vol. 39, no. 7, pp. 787-795, 2005.

[42] R. Arantes-Rodrigues, A. Henriques, M. J. Pires et al., "High doses of olive leaf extract induce liver changes in mice," Food and Chemical Toxicology, vol. 49, no. 9, pp. 1989-1997, 2011.

[43] D. Procházková, I. Boušová, and N. Wilhelmová, "Antioxidant and prooxidant properties of flavonoids," Fitoterapia, vol. 82, no. 4, pp. 513-523, 2011.

[44] A. Grüter, U. Friederich, and F. E. Würgler, “The mutagenicity of edible mushrooms in a histidine-independent bacterial test system," Food and Chemical Toxicology, vol. 29, no. 3, pp. 159$165,1991$.

[45] O. Sterner, R. Bergman, E. Kihlberg et al., "Mutagens in larger fungi. I. 48 species screened for mutagenic activity in the Salmonella/microsome assay," Mutation Research, vol. 101, pp. 269-281, 1982.

[46] O. Sterner, R. Bergman, C. Franzén, E. Kesler, and L. Nilsson, "Mutagens in larger fungi II. The mutagenicity of commercial pickled Lactarius necator in the Salmonella assay," Mutation Research Letters, vol. 104, no. 4-5, pp. 233-237, 1982. 
[47] P. Morales, E. Bermúdez, B. Sanz, and P. E. Hernández, “A study of the mutagenicity of some commercially canned Spanish mushrooms," Food and Chemical Toxicology, vol. 28, no. 9, pp. 607-611, 1990.

[48] D. Granato, F. C. U. Katayama, and I. A. Castro, "Assessing the association between phenolic compounds and the antioxidant activity of Brazilian red wines using chemometrics," LWTFood Science and Technology, vol. 43, no. 10, pp. 1542-1549, 2010.

[49] E. Gebhart, "Anticlastogenicity in cultured mammalian cells," Mutation Research, vol. 267, no. 2, pp. 211-220, 1992.

[50] T. Kada, T. Inoue, and N. Namiko, Environmental Mutagenesis and Plant Biology, Praeger, New York, NY, USA, 1982.

[51] T. Kada, "Environmental and biological factors suppressing induction of mutagens," Toxicology Forum, vol. 6, pp. 580-589, 1983.

[52] S. I. R. Franke, D. Prá, B. Erdtmann, J. A. P. Henriques, and J. da Silva, "Influence of orange juice over the genotoxicity induced by alkylating agents: an in vivo analysis," Mutagenesis, vol. 20, no. 4, pp. 279-283, 2005.

[53] N. Kalogeropoulos, A. E. Yanni, G. Koutrotsios, and M. Aloupi, "Bioactive microconstituents and antioxidant properties of wild edible mushrooms from the island of Lesvos, Greece," Food and Chemical Toxicology, vol. 55, pp. 378-385, 2013.

[54] R. Chiaramonte, E. Bartolini, P. Riso et al., "Oxidative stress signalling in the apoptosis of Jurkat T-lymphocytes," Journal of Cellular Biochemistry, vol. 82, no. 3, pp. 437-444, 2001.

[55] G. Johnsy and V. Kaviyarasana, "Antimicrobial and antioxidant properties of Trametes gibbosa (Pers.) Fr," Journal of Pharmacy Research, vol. 4, pp. 3939-3942, 2011.

[56] M. Kamiyama, M. Horiuchi, K. Umano, K. Kondo, Y. Otsuka, and T. Shibamoto, "Antioxidant/anti-inflammatory activities and chemical composition of extracts from the mushroom Trametes versicolor," International Journal of Food Sciences and Nutrition, vol. 2, pp. 85-91, 2013.

[57] J.-L. Mau, C.-N. Chang, S.-J. Huang, and C.-C. Chen, "Antioxidant properties of methanolic extracts from Grifola frondosa, Morchella esculenta and Termitomyces albuminosus mycelia," Food Chemistry, vol. 87, no. 1, pp. 111-118, 2004.

[58] I. Palacios, M. Lozano, C. Moro et al., "Antioxidant properties of phenolic compounds occurring in edible mushrooms," Food Chemistry, vol. 128, no. 3, pp. 674-678, 2011.

[59] C. A. Rice-Evans, N. J. Miller, and G. Paganga, "Structureantioxidant activity relationships of flavonoids and phenolic acids," Free Radical Biology \& Medicine, vol. 20, no. 7, pp. 933956, 1996.

[60] M. Bimakr, R. A. Rahman, F. S. Taip et al., "Comparison of different extraction methods for the extraction of major bioactive flavonoid compounds from spearmint (Mentha spicata L.) leaves," Food and Bioproducts Processing, vol. 89, no. 1, pp. 67-72, 2011. 

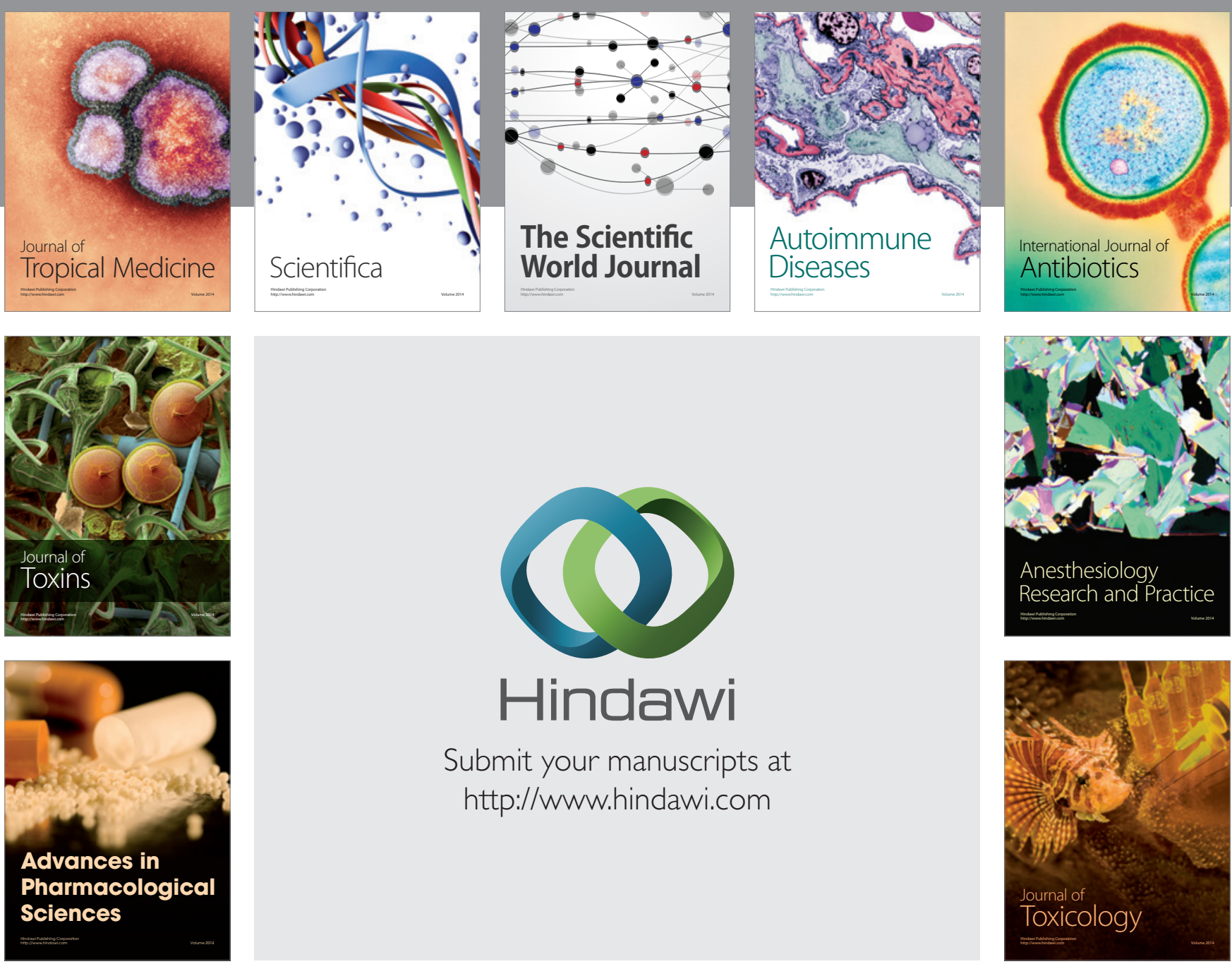

\section{Hindawi}

Submit your manuscripts at

http://www.hindawi.com
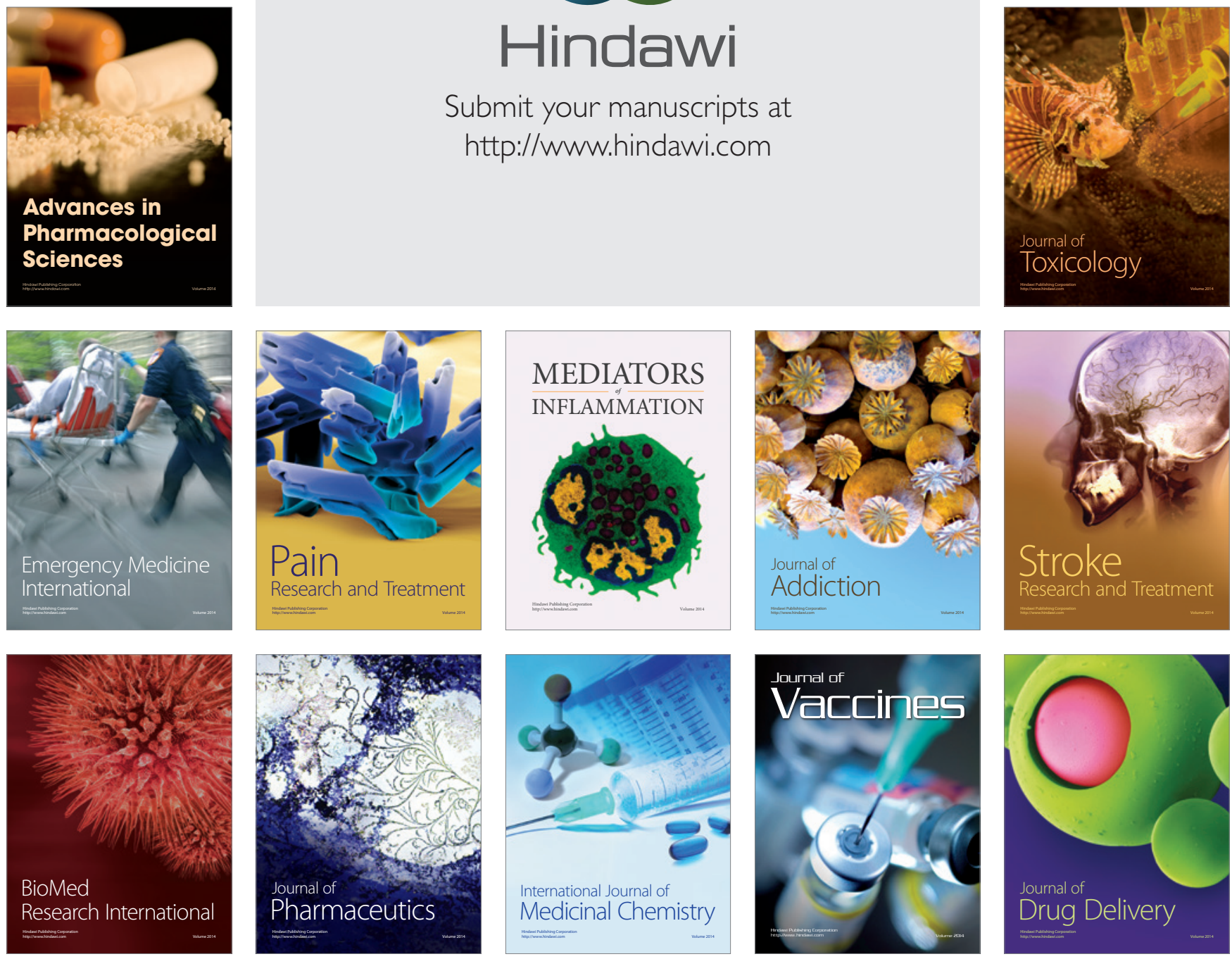